\title{
神経回路網を用いたフローグラフの 静的スケジューリング
}

$\begin{array}{lllll}\text { 非会員 } & \text { 中 } & \text { 島 重 } & \text { 義 } & \text { (大阪市 大) } \\ \text { 非会員 佐 } & \text { 藤 } & \text { 清 } & \text { 次 } & \text { (産業技術短大) } \\ \text { 正員 岡 } & \text { 本 次 } \text { 郎 } & \text { (大阪市大) } \\ \text { 正員 山 } & \text { 一 } & \text { 美 } & \text { (大阪市大) }\end{array}$

Statical Scheduling of Flow Graphs Using Neural Networks

Shigeyoshi Nakajima, Non-member (Osaka City University), Kiyotsugu Satoh, Non-member (College of Industrial Technology), Jiro Okamoto, Member, Kazumi Yamashita, Member (Osaka City University)

In the problem of scheduling data flow computers, the optimization of scheduling needs much cost. The cost often increases in non-polynomial order as the number of the processing elements and tasks increases. Many studies have been tried to decrease the order. We have used Hopfield-type neural network model for this problem. We have achieved the reduction of calculation cost in proportion as the number of tasks and the number of processing elements. Our algorithm schedules flow graphs onto the data flow architectures.Our algorithm optimizes communication delays and parallel processing delays only on the critical path of the graph. So the result of our scheduling is more superior to therecent other studies which employs neural network models. Our method is so good at being processed in parallel for it employs neural networ model.

キーワード:静的スケジューリング、フローグラフ.データフロー, 神経回路網, Hopfield, 最適化

\section{1.はじめに}

データフロー型計算機の研究が進むにつれて, デー タフロー型計算機を処理要素とし, その間を通信路で 結合してマルチプロセッサを構成し，そのうえで負荷 分散を動的(1)(2) に，あるいは静的(3)〜(5) に行う研究も なされている。このスケジューリング，あるいは負荷 分散という問題については, 過去より様々な研究がな されてきている(6)(7)

動的な負荷分散はそのための特別な機構を必要と し，それだけハードウェア資源を余分に消費する。

静的な負荷分散はハードウェア資源を消費すること はないが，実行前に負荷の分布状況を予測しなければ ならないので，負荷割当に前間がかかる(3)(4)。

大塚ら ${ }^{(5)}$ の手法は, フローグラフの負荷分散を行
うにあたって，幾種類かのレベルを節点に付け，それ をヒューリスティック值として，リストスケジューリ ングを用いたものである。節点数を $N$ とするとここ の手法は, レベル付けに $O\left(N^{2}\right)$ のオーダの割当てに 要する時間（割当てコスト）がかかる。

小柳ら ${ }^{(8)(9)}$ は，ノイマン型マルチプロセッサの負荷 分散を組合せ論的なエネルギー最小化問題の一つとし て定式化し, Hopfield 型の神経回路網(10)の手法が適 用できることを示した。

著者らはこれに対し、フローグラフの静的な負荷の 割当に対して, 神経回路網の手法が適用できることを 示した ${ }^{(11(2)} \times$ 本論文では, クリティカルパスの上の 遅れだけを最小化することが可能なことと，処理要素 数をPとしたとき，その割当てコストのオーダが $O(N \times P)$ となることを示す。

電学諞C, 112 巻 3 号, 平成 4 年 
小柳らの手法は, タスクダラフのタスク間でそれら が同時に生起する確率があらかじめわかっていなけれ ば割当てができなかった。また，データの授受を行う夕 スクが別の処理要素に割当てられた場合の通信コスト の計算をし，すべてのタスク間での並列処理されるた めの遅れ（並列処理コスト）と，通信のための遅れ (通信コスト)の総和を最小化するようエネルギ一関 数の設定を行った。彼らの手法は, タスク間に実行順 序に関して半順序関係が成立しない場合には負荷分散 法として利用できる。しかし，半順序関係が成立する 場合には，グラフのクリティカルパス上だけではな く，その他の部分の並列処理コストと通信コストをを 加算した值を最小化して扔り，負荷分散の評価法とし ては正確ではない。

本手法はデータフロー型の処理要素からなるマルチ プロセッサシステムに，フローグラフを静的に割当て る問題を対象としている。グラフの先行関係において 半順序関係が成立する場合には，クリティカルパスが 定義でき，このう忩の逢れを総和したものがグラフの 遅れとなり，プロセッサにおける遅れを正確に表現 している。著者らは,クリティカルパスの概念を Hopfield 型の神経回路網に適応できるように拡張し てクリティカルパス責献度を定義し，これによりクリ ティカルパス上の遅れのみを加算するようにエネルギ 一関数を設定することに成功した。フローグラフ上 で,データの授受が行われる節点の組の数は節点数に 比例するので $\mathrm{kN}$ とし，処理要素の数を $P$ とすると, クリティカルパス貢献度の算出のために必要とする計 算コストの才一ダは $O(N \times P)$ となる。

以下，第 2 章では神経回路網による節点の割当てに ついて，第3章ではタリティカルパス貢献度につい て，第4章ではその実験結果について，それぞれ述べ る。

\section{2. 神経回路網による割当て}

\section{〈2.1〉神経回路網によるエネルギー関数の最小化}

Hopfieldは，次式で表されるエネルギ一閔数 $E$ を 最小化する神経回路網モデルを提案した。

$$
E=\sum_{i} \sum_{j} T_{i j} V_{i} V_{j}+\sum_{i} I_{i} V_{i}
$$

モデルは次のシステム方程式で与えられる。

$$
\begin{array}{r}
\frac{d U_{i}}{d t}=-\sum_{i \neq j} T_{i j} V_{j}+I_{i} \\
\left(T_{i j}=T_{j i}\right)
\end{array}
$$

$V_{i}$ はニューロン $\nu_{i}$ 出力であり， 0 から1までの

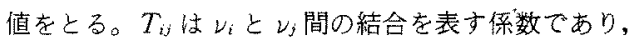

$I_{i}$ は $\nu_{i}$ の入力を示す。 $\nu_{i}$ の内部状態 $U_{i}$ と出力 $V_{i}$ は 次の関係にある。

$$
V_{i}=g\left(U_{i}\right)=\left\{\exp \left(-U_{i} / T\right)+1\right\}^{-1}
$$

$U_{i}$ と $E$ とは次式の関係にあるから， $U_{i}$ が時間々 共に最急降下法に基づいて $E$ の最小值(一般には極小 値）に収束する。

$$
\frac{d U_{i}}{d t}=-\frac{\partial E}{\partial V_{i}}
$$

よって，問題の拘束条件と最小化させるべき佪を (1)式の形で表現できれば，Eの值を最小化する組 合せ論的最小化問題が解決できる。著者らは，これを フローグラフの処理要素への最適負荷割当てに適用し た。

\section{〈2・2〉神経回路網による負荷割当ての表現}

データフロー型計算機の仕事をフローグラフで表し たとき,グラフの節点は一つのタスタ(命令)を表す。 $n$ をある節点とし， $p$ をある処理要素とする。二工 一ロン $\nu_{n p}$ の出力 $V_{n p}$ が 1 のき, 節点 $n$ が処理要 素pに割当てられたとする。ニューロン $V_{n p}$ が 0 のとき, 節点 $n$ は処理要素 $p$ に割当てられ ないとする。この $V_{n p}$ の值は次の条件を満たす必要 がある。

(i) $V_{n p}$ が1または 0 あること。そうでないと負 荷割当てが決定しえない。

(ii) 節点 $n$ が処理要素 $p$ に存在すれば，ほか心 処理要素上には存在できない。

条件の( i ) は次の值を最小化する項をエネルギ一関 数に加えることで実現できる。

$$
a_{1}=\sum_{n} \sum_{p} V_{n p}\left(1-V_{n p}\right)
$$

条件の（ii）は次の值を最小化する項をエネルギー関 数に加えることで実現できる。

$$
a_{2}=\sum_{n}\left\{1-\left(\sum_{p} V_{n p}\right)^{2}\right\}
$$

〈2・3〉通信コスト $V_{n p}$ の值により, 計算順序 を各要素に割当てたときの通信コストと並列実行コス トが計算できる。

通信コストとは, 異なる処理要素の間でデータが授 受されるときに費やされる通信時間である。並列実行 コストとは, 複数の命令が同じ処理要素で同じ時刻に 実行されるときの実行の達れである。複数の夕スクが 同じ時刻に実行されても，それぞれ暴なる処理要素上 で実行されれば並列処理遅れは起きない。

簡単のために，通信路が单位時間内に処理できるデ 一タ量, つまりスループットは一定であると仮定す る。この值を $K / 2$ とする。そして，また，ある時刻 tに拀いて通信路上に存在するデータ量を $d_{a}(t)$ とす 
る。これは,パケット通信の場合では通信路の中のパ ケット数に対応する。そのうちの一つが通信路を通過 するに必要とされる時間の期待值を delay_c $c(t)$ とす る。ここで時刻 $t$ においてプロセッサ間の通信に要す るデータの転送時間の分布が一様分布であると仮定す る。つまりデータが通信路を通る時聞にばらつきがあ るが，そのばらつきには偏りがないとする。そうする と，通信路がデー夕量 $d_{a}(t)$ をすべて転送するに必要 な時間は, delay_c(t)の2 㥉になる。よって次のよ うになる。

$$
\begin{aligned}
& 0.5 \times K=d_{a}(t) /\{2.0 \times \text { delay_c } c(t)\} \\
& K=d_{a}(t) / \text { delay_c }(t)
\end{aligned}
$$

従って, delay_c は $d_{a}(t)$ に比例する。

delay_c $(t)=d_{a}(t) / K$

節点 $n$ から節点 $m$ にデー夕が渡されるとする。 と $m$ が別の処理要素に割当てられたときには，ての デー夕は通信路を伝わって移動する必要がある。次の 式が1のとき，節点 $n$ から節点 $m$ に渡されるデータ は通信路を通ることになる。

$$
\sum_{p} \sum_{q} V_{n p} V_{m q}\left(1-\delta_{p q}\right)
$$

節点 $n$ から節点 $m$ にデータが渡されるとき $L(n$, $m)$ が 1 で，てうでないときは0であるとする。 $L(n$ ， m) はフローグラフが与えられれば一意的に与えられ る。従って, nから出るデータのうち, 通信路に出る 数は次のとおりである。

$$
\sum_{m} \sum_{p} \sum_{q} V_{n p} V_{m q}\left(1-\delta_{p q}\right) L(n, m)
$$

データが通信路に出現する時刻はnの処理が終了 した時刻である。ある時刻 $t$ に処理が終了する節点の 集合を， $s(t)$ とする。時刻 $t$ に扔ける通信路上のデー 夕の数,つまり通信路上のトラフィックは次のと㧍り である。

$$
d_{a}(t)=\sum_{n \in S(t)} \sum_{m} \sum_{p} \sum_{q} V_{n p} V_{m q}\left(1-\delta_{p q}\right) L(n, m)
$$

$n \in S(t)$ なる $n$ から出るデータの遅机は, 上式に 比例する。

$$
\begin{aligned}
\operatorname{delay}_{-} c(t)= & \sum_{n \in S(t)} \sum_{m} \sum_{p} \sum_{q} V_{n p} V_{m q} \\
& \times\left(1-\delta_{p q}\right) L(n, m) / K \cdots
\end{aligned}
$$

小柳らの手法では，以下に述べるようにクりティカ ルパスを考慮せずに， $n \in S(t)$ なる節点 $n に$ 関して 総和をとり，更に時刻 $t$ に扔けるデータの遅れの総和 をとっている。すなわち，

$\sum_{n \in S(t)}$ delay $_{-} c(t)$

であり、これをすべての $t$ について総和をとると次式
になる。

$$
a_{3}=\sum_{t} \sum_{n \in S(t)} \text { delay_c } c(t)
$$

第 3 章では，更にクリティカルパスを考慮した場合 の通信コストの計算法を示す。

〈2・4〉 並列処理コスト ある節点 $n$ が処理要素 $p$ に割当てられ，その処理が開始される時刻をてとす る。実際に $n$ が $p て ゙$ 処理されるための所要時間を delay_p(n, $p)$ とする。時刻 $\tau$ において処理される節 点の集合を $D(\tau)$ とする。 $n$ をで処理するために必 要な最小時間をdelay_ $p(n)$ とする。時刻てにおい て，pに存在する節点の数は次式で与えられる。

$$
\sum_{m \in D(\tau)} V_{m p}
$$

かにおいて $n$ が処理されるときの遅れは上式に比例 するものと仮定する。これは，ハッシュキーを用いる 機構が，ハッシング対象の数に比例してハッシュ衝突 を起こす(13)ことなどから，適当な仮定であると思わ れる。比例定数を $z$ とすと， delay_$p(n, p)=$ delay_ $p^{\prime}(n)+z \sum_{m \in D(\tau)} V_{m p}$

小楖らの手法ではクリティカルパスを考慮せず，す

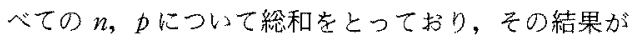
次式のようになる。

$\sum_{n} \sum_{p}$ delay_p $(n, p)$

(16)式を $V_{n p}$ の重みを付けて総和をとると次のよ うになる。

$$
a_{4}=\sum_{n} \sum_{p} \text { delay_p }(n, p) V_{n p}
$$

〈2.5〉エネルギー関数 (5), (6), (13), (17)式の項を適切な重み定数 $w_{i}$ にって荷重加算し たものをエネルギ一関数とする。

$$
E=\sum_{i} w_{i} \times a_{i}
$$

このEより，(4)式と同様に次の式に嗞って $U_{n p}$ を時間変化させる。

$$
\frac{d U_{n p}}{d t}=-\frac{\partial E}{\partial V_{n p}}
$$

ホップフィールドの提案した神経回路網モデルは, 図1のように, ニューロンとそれらの間の線形接続上 り成り立っていた。しかし，(19)式の時間変化を算出 するためには，システムは图2の上うに，線形な接続 だけではなく，時刻ごとに通信路のトラフィックを算 出する部分と, 処理要素上の節点数を算出する部分と が必要になる(14)。このような非線形の回路網モデル であっても偏微分が正磪に算出できればこう配法の原 理によってシステムは収束する。 


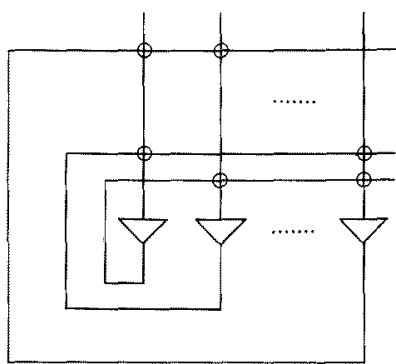

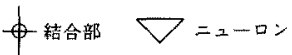

图 1 神経回路網モデル

Fig. 1. Neural network model.

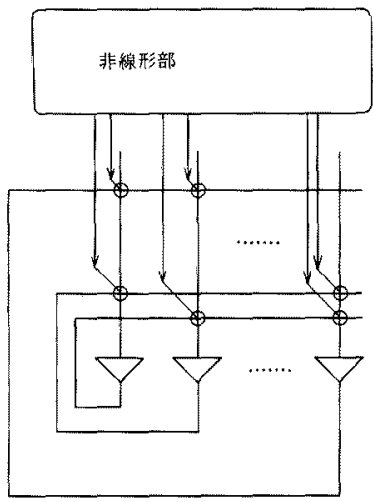

図 2 非線形部のある神経回路網モデル Fig. 2. Neural network model with nonlinear unit.

\section{3. クリティカルパス賣献度}

〈3・1〉クリティカルパス上の遅れ（19）式に従 ってシステムを変化させた結果は，(18)式の值を最小 化させる。これはく2・2〉節の条件 (i ) と(ii)を満足さ せたうえで，並列による遅れと通信による遅れを最小

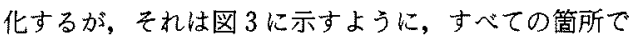
の遅れの総和である。実際に計算の必要のある遅れ は，図 4 に示すようにクリティカルパス上の節点の遅 れと節点閒の遅れのみの総和である。そのために，次 のようにして，クリティカルパスの上にある遅れのみ の総和を計算し、それを新たにエネルギ一関数とする。

節点 $n$ がクリティカルパス上にあるときに cri $(n)$ が1でそうでないときに0であるとする。(11)式を次 の上うに変える。

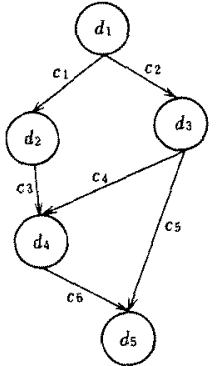

$c_{i}$ : 通㯰による遇れ

$d_{i}:$ 亚行実行による遇れ

図 3 すべての部分の遅れ

Fig. 3. Sum of the delays all over the graph.

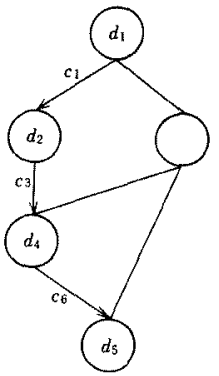

図 4 クリティカルパスの上の遅れ

Fig. 4. Sum of the delays on the critical path.

$$
\begin{aligned}
\text { delay_c } c(\tau)= & \sum_{n \in S(\tau)} \sum_{m} \sum_{p} \sum_{q} V_{n p} V_{m q} \\
& \times\left(1-\delta_{p q}\right) L(n, m) / \\
& K \operatorname{cri}(n)_{\mathrm{cri}}(m) \ldots
\end{aligned}
$$

上式に従って(13)式の $a_{3}$ を計算する。また，(15) 式の代わりに次の式を用いる。

$$
\begin{aligned}
& \text { delay } \_p(n, p) \\
& =\mathrm{c}_{r i}(n) \times\left\{\text { delay_} p^{\prime}(n)+z \sum_{m \in D(r)} V_{m p}\right\}
\end{aligned}
$$

上式に従って(17)式の $a_{4}$ を計算する。このように すれば，クリティカルパス上の遅れのみが総和され る。負荷割当てが決定されているときつまり $V_{m p}$ が 〈2・2〉節における条件の(i)と（ii)を満足していると き, 節点 $n$ に対して, それが存在する姏理要素 $p$ が 唯一性をもって决定される。このとき，クリティカル パスの検出は，次のように行う。例えば，図 5 の太丸 で示したような，最も遅く終了する節点をまず最初に 選ぶ。この節点がタリティカルパスの終端節点であ 


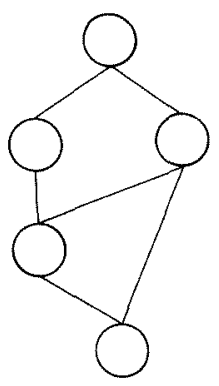

図 5 最已遅い節点

Fig. 5. The node which is processed latest.

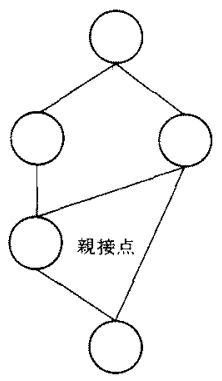

図 6 親節点

Fig. 6. Mother node.

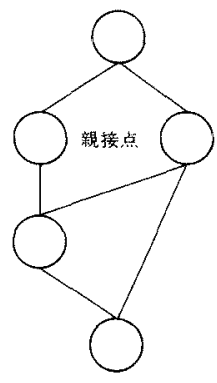

図 7 もう一つの親節点

Fig. 7. Another mother node.

る。クリティカルパスの上では，ある節点 $n$ とその 親節点 $m$ は次の関係にある。

「節点 $n$ に最も遅くデータを渡す節点 $m$ がタリテ イカルパス上での $n$ の親節点である。

よって，図6のように終端節点の親節点を探して， それをクリティカルパス上の新なな節点とする。次 に，図7のようにその節点の親節点を探す。
節点 $n$ に対して，それが存在する処理要素 $p$ が唯 一性をもって決定されないときは，この方法ではクり ティカルパスが決定できない。このときの $\mathrm{cri}(n) の$ 算出法を〈3・2〉，〈3・3〉節に述べる。

〈3・2〉 ニューロンに対応した開始時間 節点 $n$ に対して，それが存在する処理要素 $p$ が唯一性をも つて決定されないときは，節点 $n$ の開始時刻が決定

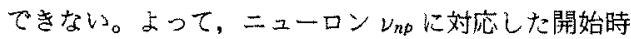
刻 $\operatorname{start}(n, p)$ と終了時刻 end $(n, p)$ を算出する。 ここで，この開始時刻と終了時刻の算出は次の条件を 満たすものとする。

（i）割当てが確定したとき実際の時刻に一致す る。

（ii）割当てが確定しないとき $V_{n p}$ に応じて時刻 を決定。

まず, フローグラフの開始節点 $s の \operatorname{start}(s, p)$ を 0 とする。このとき, end $(s, p)$ は次の式で求めら れる。

$$
\begin{aligned}
\operatorname{end}(s, p)= & \operatorname{start}(s, p)+\text { delay } \_(s) \\
& +z \sum_{m \in D(t)} V_{m p} \\
\text { ただし, } & \\
s \in D(\tau) &
\end{aligned}
$$

処理要素 $q$ にある節点 $m$ が処理要素 $p$ にある節点 $n$ からデー夕を受取るとすると, 受取る時刻 $\tau(m, q$, $n, p)$ は, end $(n, p)$ に通信路を通る遅れ時間が加算 された值となる。

$$
\begin{aligned}
& t(m, q, n, p)=\operatorname{end}(n, p) \\
& \quad+\sum_{m^{\prime} \in S(\tau)} \sum_{m} \sum_{p} \sum_{q} V_{m p}^{\prime} V_{m q}\left(1-\delta_{p q}\right) \\
& \quad L(n, m) / K \\
& \text { ただし, } \\
& n \in S(s)
\end{aligned}
$$

処理要萃 $q$ にある節点 $m$ が節点 $n$ からデータを受 取る時刻 $\tau^{\prime}(m, q, n)$ は， $V_{n p}$ が 0 加 1 に収東する 過程において $V_{n p}$ の变化が反映するように，しかも， 収束したとをに実際の時刻と一致するようにてをを $V_{n p}$ の重みで荷重平均したものとする。

$$
\begin{aligned}
& \tau^{\prime}(m, q, n) \\
& \quad=\left\{\sum_{p} \tau(m, q, n, p) V_{n p}\right\} /\left\{\sum_{p} V_{n p}\right\}
\end{aligned}
$$

处理要素 $q$ にある節点 $m$ の開始時刻 $\operatorname{start}(m, q)$ は $\tau^{\prime}(m, q, n)$ の最大値である。 


$$
\left.\begin{array}{l}
\operatorname{start}(m, q)=\max _{n}\left\{\tau^{\prime}(m, q, n)\right\} \\
\text { ただし, } \\
L(n, m)=1
\end{array}\right\}
$$

このようにして, ニューロン $\nu_{n p}$ の開始時刻 start $(n, p)$ と終了時刻 end $(n, p)$ が算出可能である。こ $\sigma \operatorname{start}(n, p)$ と end $(n, p)$ に従って, クリティカ ルパス貢献度 $\operatorname{cri}(n)$ を算出する方法について次節で 述べる。

〈3.3〉 クリティカルパス貢献度 節点 $n$ に対し て，それが存在する処理要素 $p$ が唯一性をもって決 定できないときは, $\operatorname{cri}(n)$ は〈3・1〉節で述べたように 0あるいは1に決定できない。ここで, cri $(n)$ の值域 を抎張して 0 と 1 の間の連続值とし, $\operatorname{cri}(n)$ を改めて クリティカルパス頁献度として定義する。これはその 節点がクリティカルパスの成立にどれだけ貢献してい るかを示す量である。クリティカルパス貢献度の満た すべき条件として次を挙げる。

(i) $V_{n p}$ が0か1に収束したときは，クリティカ ルパス貢献度は 0 か 1 亿収束し, その值がクリティカ ルパスの経路と一致すること。

(ii）クリティカルパス貢献度は $V_{n p}$ に応じて時 刻 $\tau^{\prime}$ の算出の場合と同様に分配されていること。

すな⿰ち,クリティカルパス貢献度の計算は次のよ うにして行う。終端節点のクリティカルパス貢献度を 1 とする。そして, 次の方法で $V_{n p}$ の值に応じて, フローグラフの遅れ時間の多い節点のほうにクリティ カルパス貢献度が大きくなるように節点をさかの情っ て順次決定してゅく。伝搬させていく。

クリティカルパス貢献度の確定した節点を $m$ とす る。 cri $(m)$ を $V_{m q}$ に従って処理要素に分配する。す なわち， $\nu_{m}$ の貢献度は次式となる。

$$
\operatorname{cri}(m) V_{m q}
$$

$L(n, m)=1$ を満たす $n$ の中で，(25)式を満たす $n$ を選び，これを $p_{a}(m, q)$ で表す。

$$
n=p_{a}(m, q)
$$

ある $n$ に対し， $L(n, m)=1$ を満たすすべての $m$ の cri $(m)$ が決定されているとき， $n$ は (27)式を満た す $m$ からのみ $V_{m q}$ を重みとして cri $(m)$ の伝搬を受 ける。これは, 本節で述べた条件（i）と（ii）を満たす ものである。 $\operatorname{cri}(n)$ は次の式で与えられる。

$$
\operatorname{cri}(n)=\sum_{n=p_{\alpha}(m, q) L(n, m)=1} \operatorname{cri}(m) V_{m q}
$$

(28)式に従って，すべての $n$ に対し cri $(n)$ を算出 する。このとき，

$$
\begin{aligned}
& a_{3}=\sum_{n} \operatorname{cri}(n) \times \text { delay_c } c(\tau) \\
& \text { ただし, } \\
& n \in S(\tau) \\
& a_{4}=\sum_{n} \sum_{p} \operatorname{cri}(n) \times \text { delay } \__{\perp}(n, p) V_{n p}
\end{aligned}
$$

となる。

\section{4. 実験結果}

本方式による割当てコストと割当てられた結果の有 効性を検証するために計算機シミュレーションを行つ た。

〈4・1〉割当てコストの評価 シミュレーション プグラムとして, 逐次型アルゴリズムを用いて上記 の負荷割当てを行ったときに必要なコスト。つまり処

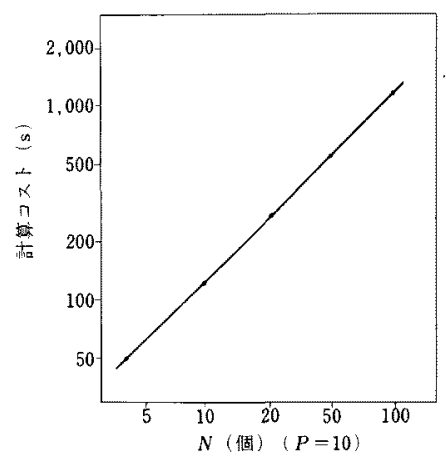

図 8 割当てコストと接点数 $N$

Fig. 8. Scheduling cost and the number of nodes $N$.

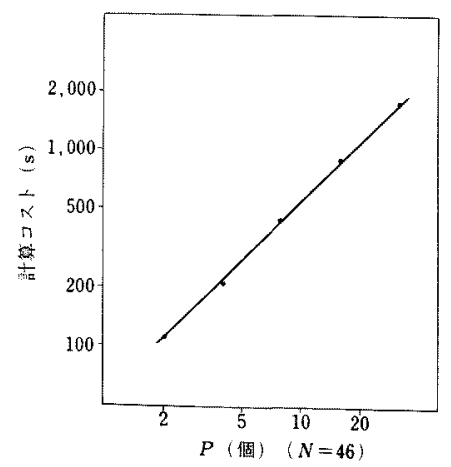

図 9 割当てコストと処理要素数 $P$ Fig. 9. Scheduling cost and the number of processing elements $P$. 


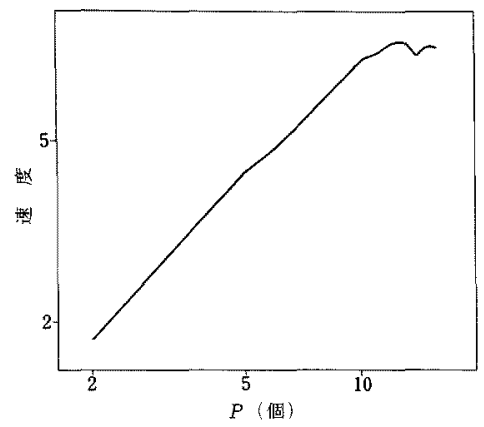

整はP=10ちきが1であるとしている

图 10 速度と好理要系数 $P$

Fig. 10. Speed and the number of Processing elements $P$

理にかかる時間は, 処理対象のフローグラフの節点数 $N$ と好理要素数 $P$ の積に比例する。 $P$ が一定のとき には，処理時間は $N$ に比例する。図 8 にカスケードサ 么,すなわち, $\sum a_{i}$ を計算するフローグラフを $P$ 個の 処理要素に割当てたときに割当てにかかる時間の樣子 を両対数のグラフで示す。また，Nが一定のときには， 時間はPに比例する。図9にその様子を同様に示す。 図 8, 図9より割当てコストは $O(N \times P)$ であるこ とが示される。

著者らが実行したシミュレーションプログラムは逐 次型であったが，もし，並列型の Hopfield タイプの 神経回路網をシミャレーション可能なシステムを用い るならば，割当ての計算に必要な時間は大幅に短縮さ れる。

〈4・2〉割当て結果次に, 本方式による負荷割 当ての有効性を検証するために, 次のように実験を行 つた。10 個の直列した加算を 10 列，亚列に実行する アルゴリズムを $P$ 個の処理要素に割当てる。図 100 グラフには処理要素の数が増えるに従って処理速度が 向上することを示し，これは台数効果と呼ばれる。し 加し, 処理要素数が 10 台を超えると速度の向上が飽 和している。これは，フローグラフ自体のもつ亚列性 が 10 であるから，10程度の姏理要素数で飽和に達し たものと推察される。フローグラフの荊列性を增加さ せれば，増加した值において飽和が生じることが予測 される。

Hopfield 型神経回路網の一般的な欠点として，工 ネルギーの最小点にではなく，極小点へ収束するとい う問題が常に挙げられるが, 回路網の動作にがウス雑
音を加えるなどの試みがなされており，それらの研究 の結果に期待する。

\section{5. 終りに}

データフロー型計算機のスケジューリング問題を, Hopfield の神経回路網のエネルギ一最小化原理を用 いて解くことができた。そして，Hopfield型の神経 回路網を用いて逐次型アルゴリズムを用いて負荷割当 てを行った。負荷割当てに必要なコストがフローグラ フの節点数と処理要素の数に比例することを確認し， 従来の方法より優れていることを示した。また，触荷 割当ての結果に台数効果が表れることも確認できた。

今後の研究橦題以，ここで述べた手法をデータフロ ーマシンとは異なる型の並列タスク，例えば，データ フロー型計算機による画像処理演算や，ロボットの制 御などの負荷割当てに，適用範国を広げていくことで あると考えている。

(平成 3 年 4 月 1 日受付)

\section{文献}

（1）平木・関口・島木：「並列部算機におけるネットワークを网

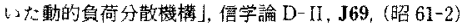

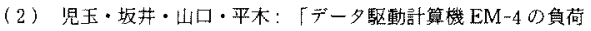
分散」，情報好理学会第 38 回全大, (III), p. 1416 (平元)

(3) S. H. Bokhari: "Partitioning Problems in Parallel, Pipelined, and Distributed Computing", IEEE Trans. Comput., C-37, 48 (1988)

(4) H. Kasahara \& S. Narita: "Practical Multiprocessor Scheduling Algorithms for Efficient Parallel Processing". ibid., C-33, 1023 (1984)

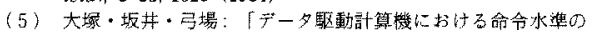
静的負荷分散」，信学枝報，cpsy 86-48，75(日召 61)

（6）坂杫：「前列計算機におけるスケジューリンダ上角荷分 散了”, 情報姃理, 27, 1031 (昭 61-9)

（7）田中・管原：「並列化マルチプロセッサ・スケジェーリング. アルゴリズムの䒠マルチプロセッサ上でインプッント1. 情報处理学会第 38 回全大（III）、p. 1452 (平元)

(8) 田中・Canfieldy・小楖・妄地：「二ューラルネット交用いた

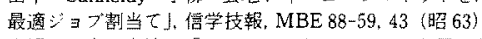

（9）小楖・田中・玄地：「二ューラルネットワークを第いた最適 タスフ割当て」,コンピュートロール，29，78（平 2)

(10) J. J. Hopfield \& D. W. Tank: "Neural Computation of Decisions in Optimization Problems". Biological Cyber. netics, 52, 141 (1985)

（11）中島・佐藤・山下：「ホッフフィールトの神経回路網モデ を用いたフローダラフのデータフローマルチナ゙セッサへの

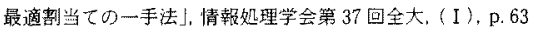

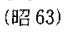

（12）中鳥・佐藤・山下：「フローク゚ラフのクリティカルパス上の

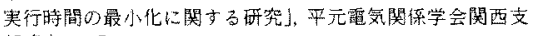
部遳大, p. G 234

（13）山崎，他：「外部ハッシュキ一を用いたデー多駆動形实行制 御方式の性能詊便」，データフローワータショップ1987 予稠 集, p. 287

(14) K. Tsutsumi \& H. Matsumoto: "Neural Computation and Learning Strategy for Manipulator Position Control", Proc. of IEEE First Annual International Conference on Neural Networks (KNN-87), p. 525 (1987) 


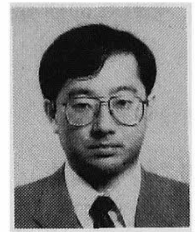

中 島 重 義 (非会員)

昭和 59 年京都大学大学院修士課程修 了, 62 年同博士課程単位取得退学。同 年大阪大学工学部助手。現在に至る。主 として, ディジタル画像処理, 神経回路 網, 並列処理などの研究に従事。情報処理学会会員, 人工 知能学会会員, 電子情報通信学会会員, IEEE 会員。

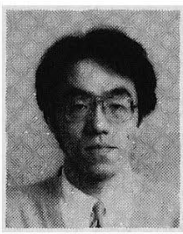

\section{佐 藤 清 次（非会員）}

昭和 56 年大阪市立大学大学院修士課 程修了。60年同博士課程単位取得退学。 同年鉄鋼短大（現, 産業技術短大) 講 師。平成元年同助教授。現在に至る。工 学博士。現在, 高速画像処理プロセッサ, 画像高能率符号 化の研究に従事。情報処理学会, 電子情報通信学会会員。

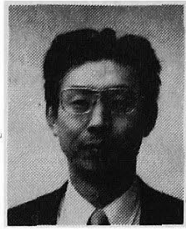

岡 本 次 郎 (正員)

昭和 37 年京都工芸瀻維大学織維工学 科卒業。39 年大際市立大学大学院修士 課程修了。同年同大学工学部助手。 45 年同講師, 63 年同助教授, 現在に至る。 工学博士。この間, 音声情報処理, パイオニクス, 二次元 ディジタルフィルタの安定性, ニューラルネットワークな どの研究に従事。電子情報通信学会, IEEE 会員。

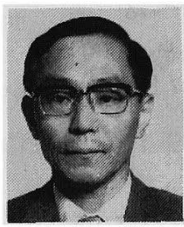

$$
\text { 山 下 - 美 (正員) }
$$

昭和 27 年大阪大学工学部通信工学科 卒業。神戸工業(現富士通)（株)勤務を 経て, 29 年大阪市立大学工学部勤務, 45 年同教授（情報システム工学講座担 当), 現在に至る。工学博士。この間, ディジタル通信, 音声高能率符号化, 視聴覚神経系の情報処理などの研究を 経て, 現在, 音声認識, 情報ネットワーク, ディジタル信 号処理, 動画像高能率符号化, 並列処理, ニューラルネッ トワークなどの研究に従事。電子情通信学会, IEEE 会員。 